\title{
Determinants of Diabetic Complication Among Adult Diabetic Patients in Debre Markos Referral Hospital, Northwest Ethiopia, 2018: Unmatched Case Control Study
}

This article was published in the following Dove Press journal:

Diabetes, Metabolic Syndrome and Obesity: Targets and Therapy

\author{
Bekalu Bewket Kidanie' \\ Girma Alem' \\ Haymanot Zeleke' \\ Mihretie Gedfew' \\ Afework Edemealem ${ }^{2}$ \\ Atsedemariam Andualem (D) ${ }^{2}$ \\ 'Department of Nursing, College of \\ Health Science, Debre Markos University, \\ Debre Markos, Ethiopia; ${ }^{2}$ Department of \\ Nursing, College of Health Science, \\ Wollo University, Dessie, Ethiopia
}

Background: Diabetes mellitus is a group of common metabolic disorders that share the phenotype of hyperglycemia, and are caused by a complex interaction of genetics and environmental factors. Diabetes mellitus produces change in the blood vessels and therefore affects almost every part of the body.

Methods: A hospital-based unmatched case control study was conducted from February 2018 to April 2018 at Debre Markos Referral Hospital. Data were collected from 204 individuals, 136 controls and 68 cases using an interviewer-administered questionnaire and patient chart. Data were entered into EPI-data 3.1 software and exported to SPSS version 21 for analysis. Descriptive analysis including mean, median and proportions was carried out. In bivariate analysis, variables below 0.25 significance level were selected for multivariable analysis. For multivariable analysis, a backward model was selected and $95 \%$ confidence interval variables with $P$-values below 0.05 in multivariable analysis were declared as significant variables.

Results: Of the total respondents, 68 were cases and 136 were controls, with an overall response rate of $98.55 \%$. Of these respondents, $57.4 \%$ and $57.8 \%$ were males and type 1 diabetic patients, respectively. This study found that ages of $38-47(\mathrm{AOR}=5.60(1.62-19.38))$ and $>47(\mathrm{AOR}=4.81$ (1.32-17.5)), income of 1000-1499 (AOR=3.10 (1.05-9.08)), self-reported drug adherence $(A O R=5.146(1.651-16.04))$, FBS of $70-130 \mathrm{mg} / \mathrm{dL} 0.095(0.022-0.414)$ and $\geq 131 \mathrm{mg} / \mathrm{dL}(0.05$ $(0.011-0.223))$ and type 1 diabetic mellitus $(A O R=4.73(1.765-12.72))$ were significantly associated with diabetes mellitus complications.

Conclusion and Recommendations: The study identified important determinants of diabetic complications. Poor glycemic control, poor adherence, and income were found to be modifiable determinants; on the other hand, age and type of diabetic mellitus are nonmodifiable determinants of diabetic complications. Clinicians should implement a comprehensive care plan that will address patients' adherence and glycemic control problems. Keywords: diabetic complication, glycaemic control, adherence

\section{Introduction}

Diabetes mellitus (DM) is a group of common metabolic disorders that share the phenotype of hyperglycemia, and are caused by an interaction of genetics and environmental factors. There are two main forms of diabetes, type 1 (insulindependent diabetes mellitus) and type 2 (non-insulin-dependent diabetes mellitus). Type 1 diabetes accounts for $5-10 \%$ of all cases of diabetes. As of yet, there are no
Correspondence: Bekalu Bewket Kidanie Department of Nursing, College of Health Science, Debre Markos University, Debre Markos, Ethiopia

Email bewket.bekalu20I4@gmail.com 
known ways to prevent type 1 diabetes. Type 2 diabetes accounts for $90-95 \%$ of all diagnosed diabetes cases. This form of diabetes generally begins as insulin resistance and, because the body is unable to produce enough insulin to address the resistance, the pancreas may reduce the production of insulin or in the long run stop producing it. Even with the great steps that have been made in the understanding and management of type 2 diabetes, insulin resistance, and diabetes-related complications are increasing unrelieved. ${ }^{1-3}$

As it is a progressive disease, diabetic patients are frequently diagnosed with chronic complications including cardiovascular disease, nephropathy, coronary heart disease, retinopathy, and neuropathy. The prevalence of these complications of diabetes is generally expected to be proportional to the duration of diabetes and the degree of glycemic control. ${ }^{4}$

Diabetes is the leading cause of end-stage renal disease (ESRD), non-traumatic lower extremity amputations, and adult blindness. It also predisposes to cardiovascular diseases. With an increasing incidence worldwide, DM will be a leading cause of morbidity and mortality in the predictable future. No countries are escaping the diabetes epidemic, and in states worldwide it is the poor and disadvantaged who are suffering most. Indigenous communities are among those especially vulnerable to diabetes. Diabetes caused 5.1 million deaths in 2013. Every six seconds a person dies of diabetes. ${ }^{1}$

Diabetes mellitus basically produces changes in the blood vessels and therefore affects almost every part of the body. Diabetic nephropathy has become a world epidemic, accounting for a third of all cases of end-stage renal disease worldwide. ${ }^{1,6}$ More than half of nontraumatic amputations are due to diabetic complications. ${ }^{5}$

When not well managed, all types of diabetes can lead to complications in many parts of the body, resulting in frequent hospitalization and early death. People with diabetes have an increased risk of developing a number of serious lifethreatening health-related problems, increasing medical care costs and lowering quality of life. The prevalence of ESRD is 10 times higher among people with diabetes. Every $30 \mathrm{sec}-$ onds a lower limb or part of a lower limb is lost to amputation somewhere in the world as a consequence of diabetes. ${ }^{6}$

In 2015, the IDF also estimated that, in the Africa region, 14.2 million adults aged $20-79$ had diabetes, representing a prevalence of $3.2 \%$. The majority (59\%) of people with diabetes live in cities, even though the population is predominantly (61\%) rural. This region has also the highest proportion of previously undiagnosed diabetes; over two-thirds $(67 \%)$ of people with diabetes being unaware they have the disease. ${ }^{7}$

Currently, Ethiopia has been challenged by the growing magnitude of non-communicable diseases (NCDs) such as diabetes. Ethiopia is among the four countries with the highest adult diabetic populations in sub-Saharan Africa. Patient attendance rates and medical admissions related to diabetes in major hospitals have been rising.

Studies have reported that diabetes and the observed complications of diabetes are increasing over the years and are among the common reasons for inpatient admissions. In diabetes prognosis, the high morbidity and mortality compromises the quality of life, in addition to the costs needed to control diabetes and treatment of acute and chronic complications. $^{7}$

The economic burden of diabetes in 2030 is estimated to be $61 \%$ higher than in 2015 . It was estimated that the substantial burden of diabetes by the year 2030 will reach 2 trillion USD. Globally diabetes results in 527 USD expenditure yearly. ${ }^{6,8}$

Diabetic complications are becoming some of the most overwhelming problems of the 21 st century. This requires a shift in health-care priorities and up-to-date data on the complications and related factors of diabetes in Ethiopia, to help plan and prioritize health programs. Such information can be an important base for policy on diabetes prevention and treatment.

\section{Methods \\ Study Area}

The study was conducted at Debre Markos Referral Hospital in Debre Markos town from February to April 2018. Debre Markos town is the capital of East Gojam zone which is $300 \mathrm{~km}$ from Addis Ababa and $265 \mathrm{~km}$ from Bahirdar, a capital city of Amara National Regional State. The hospital was established in 1957 by Emperor H/Selassie and currently serves a population of around 3.5 million in its catchment area. In addition, there are around 100 health centers and 8 district hospitals available in the catchment area of the referral hospital. There are 109 nurses, 3 health officers, 16 general practitioners, one emergency surgeon, and five specialists.

\section{Study Design}

A hospital based unmatched case control study design was used. 


\section{Population}

Source Population

All adult diabetic patients who attended Debre Markos Referral Hospital.

\section{Study Population}

All adult diabetic patients who attended DMRH and who were available during the data collection period.

\section{Inclusion and Exclusion Criteria Inclusion Criteria}

Cases: cases were any adult, presenting to DMRH in the data collection periods with previously diagnosed diabetes mellitus of at least one year duration and with any of the following diabetic complications: hypoglycemia, hyperglycemia (DKA, HHNS), diabetic nephropathy, and diabetic foot ulcer.

Control: controls were any adult person who presented to DMRH in the data collection periods, with previously diagnosed diabetes mellitus of at least one year duration, and with no diabetic complications.

\section{Exclusion Criteria}

Those who had no documented clinical and/or laboratory evidence interest, those who died by one of the diabetes complications, those who were critically ill, or who had comorbidity illnesses like tuberculosis, malaria, and heart disease were excluded from the study.

\section{Sample Size Determination}

Sample size was computed using statical EPI INFO version 7 with major factors like being overweight, alcohol consumption, poor glycemic control, and presence of other complications with odds ratios of 2.7, 2.49, 2.71, and 3.55, respectively, taken from a previous study. ${ }^{9}$ For sample size determination, $80 \%$ power, the proportion of cases exposed, the proportion of controls exposed, and odds ratio of each variable at $95 \%$ confidence interval were considered. By considering the above assumptions the final required sample size calculated was 207 , from this 69 were cases and 138 were controls.

\section{Sampling Technique and Procedure}

A consecutive sampling technique was used.

\section{Study Variables}

The dependent variable of the study was diabetic complication and independent variables were sociodemographic and behavioral variables (age, sex, educational level, occupation, income, residence, marital status, alcohol drinking, and cigarette smoking), disease, treatment and health service related factors (type of diabetic mellitus, duration after diagnosis, family history of diabetic mellitus, type of treatment given, blood glucose measurement at home, distance from the hospital, BMI, blood pressure, self-reported adherence, glycemic control, and health education), attitude level of respondents, and knowledge level of respondents.

\section{Data Collection Tool and Procedures}

Data were collected by using an interviewer-administered structured questionnaire, developed by the principal investigator by reviewing different works of literature and from similar studies. ${ }^{9-13}$ The questionnaire was first presented in English, translated to Amharic and back to English and it has five parts which consist of closed ended questions. A pre-test was done in Finote Selam hospital among 21 individuals. The instrument was checked for validity by experts and internal consistency of attitude items and knowledge items were found to have 0.76 and 0.63 alpha coefficients, respectively. Body mass index was computed by measuring the height and weight of each individual. The procedure was as follows: heights of individuals were taken by tape measure, a standard weight machine was used, and then by using a calculator BMI was calculated for each individual by dividing their individual weight in $\mathrm{kg}$ with their height in square meters. The US National Heart, Lung and Blood Institute criteria were used to classify BMI $<18.5$ as underweight, BMI 18.5-29.9 as normal, BMI 25-29.9 as overweight and BMI $>30$ as obesity. ${ }^{14}$

\section{Data Processing and Analysis}

Data were entered using EPI-DATA 3.1 and exported to SPSS 21. Before data analysis was started, it was cleaned and coded. After that, descriptive statistics were used to summarize data. Binary logistic regression was done to determine the relationship of each independent variable with the dependent variable; variables below 0.25 were entered into a multivariable logistic regression model. Finally, variables having $p$-values $<0.05$ at $95 \%$ confidence interval were declared as significant variables for determining diabetic complications.

\section{Result}

\section{Sociodemographic Characteristics of Study Participants}

A total of 204 respondents were interviewed, with a response rate of $98.55 \%$. Out of the total participants, $117(57.4 \%)$ were male and $87(42.6 \%)$ were female. The median ages of case and 
controls were 39.5 ( $\mathrm{IQR}=28-50$ years) and $38.0(\mathrm{IQR}=27.5-50$ years), respectively. Of the 138 (67.8\%) urban dwellers, 39 were cases and 99 were controls. Regarding marital status, 126 (61.8\%) were married. Monthly income was calculates and $25(13.7 \%)$ of respondents had less than 500 ETB monthly income and 105 (57.7\%) respondents had greater than or equal to 2000 ETB monthly income. The majority of the total study participants $(202 ; 99 \%)$ are non-smokers, and 178 $(87.3 \%)$ of respondents answered that they had not been drinking alcohol (Table 1).

\section{Disease, Treatment, and Health Service Related Factors}

As the result shows, 118 (57.8\%) of the total respondents are type 1 diabetic patients. Of both type 1 and type 2 respondents, $126(61.8 \%)$ were on insulin treatment. Regarding glycemic control $126(61.8 \%)$ of the total respondents had poor glycemic control. Body mass index was calculated and $123(60.8 \%)$ of the samples were normal weight by height and $56(27.5 \%)$ were overweight (Table 2).

\section{Knowledge and Attitude Level of \\ Participants}

Knowledge and attitude of respondents were assessed, and out of the total participants, 171 (83.2\%) had good knowledge. The median attitude level was 32.00 . Out of the total participants, 110 (53.9\%) had an unfavorable attitude (Tables 3, 5 and 6).

\section{Determinants of Diabetic Complication}

In bivariate analysis age, marital status, monthly income, occupation, residence, type of drug, distance from the hospital, BMI, self-reported drug adherence, glycemic control, and type of diabetes mellitus were associated with diabetic mellitus. In multiple logistic regression ages of 38-47 (AOR=5.60 (1.62-19.38)) and $>47 \quad(A O R=4.81(1.32-17.5))$, income of 1000-1499 $(\mathrm{AOR}=3.10 \quad(1.05-9.08)), \quad$ self-reported drug adherence $(\mathrm{AOR}=5.146(1.651-16.04))$, FBS of 70-130 mg/dL 0.095 (0.$022-0.414)$ and $\geq 131 \mathrm{mg} / \mathrm{dL}(0.05(0.011-0.223))$, and type 1 diabetic mellitus $(\mathrm{AOR}=4.73(1.765-12.72))$ were found to be significantly associated with diabetes mellitus complicati ons (Table 4).

\section{Discussion}

This study aims to examine the determinants of diabetic complications among adult diabetic follow-up patients. According to this study the majority of respondents were
Table I Sociodemographic Characteristics of Diabetic FollowUp Patients at DMRH, North West Ethiopia, 2018

\begin{tabular}{|c|c|c|c|c|}
\hline \multirow[t]{2}{*}{ Variable } & \multirow[t]{2}{*}{ Category } & \multicolumn{2}{|c|}{ Frequency } & \multirow[t]{2}{*}{ Percentage } \\
\hline & & $\begin{array}{l}\text { Cases } \\
(\mathrm{N}=68)\end{array}$ & $\begin{array}{l}\text { Controls } \\
(\mathrm{N}=136)\end{array}$ & \\
\hline \multirow[t]{2}{*}{ Sex } & Male & 38 & 79 & $57.4 \%$ \\
\hline & Female & 30 & 57 & $42.6 \%$ \\
\hline \multirow[t]{4}{*}{ Age } & $18-27$ & 15 & 34 & $24 \%$ \\
\hline & $28-37$ & 15 & 32 & $23 \%$ \\
\hline & $38-47$ & 18 & 25 & $21.1 \%$ \\
\hline & $>47$ & 20 & 45 & $31.9 \%$ \\
\hline \multirow[t]{2}{*}{ Residence } & Urban & 39 & 99 & $67.6 \%$ \\
\hline & Rural & 29 & 37 & $32.4 \%$ \\
\hline \multirow[t]{8}{*}{$\begin{array}{l}\text { Level of } \\
\text { education }\end{array}$} & $\begin{array}{l}\text { Unable to read } \\
\text { and write }\end{array}$ & 22 & 35 & $27.9 \%$ \\
\hline & $\begin{array}{l}\text { Able to read and } \\
\text { write }\end{array}$ & 18 & 44 & $30.4 \%$ \\
\hline & Student & 3 & 1 & $2.0 \%$ \\
\hline & Certificate & 6 & 13 & $9.3 \%$ \\
\hline & Diploma & 9 & 26 & $17.2 \%$ \\
\hline & Bachelor degree & 8 & 14 & $10.8 \%$ \\
\hline & Masters and above & 2 & 3 & $2.5 \%$ \\
\hline & Student & 7 & 12 & $9.3 \%$ \\
\hline \multirow[t]{4}{*}{ Occupation } & $\begin{array}{l}\text { Government } \\
\text { workers }\end{array}$ & 12 & 40 & $25.5 \%$ \\
\hline & Private workers & 0 & 4 & $2.0 \%$ \\
\hline & Others & 49 & 80 & $63.2 \%$ \\
\hline & $<500$ & 9 & 22 & $15.1 \%$ \\
\hline \multirow[t]{5}{*}{ Income in ETB } & 500-999 & 10 & 15 & $12.2 \%$ \\
\hline & $1000-1499$ & 11 & 12 & $11.2 \%$ \\
\hline & $1500-1999$ & 6 & 10 & $7.8 \%$ \\
\hline & $\geq 2000$ & 32 & 77 & $53.43 \%$ \\
\hline & Single & 17 & 37 & $26.5 \%$ \\
\hline \multirow[t]{3}{*}{ Marital status } & Married & 41 & 85 & $61.8 \%$ \\
\hline & Divorced & 6 & 3 & $4.4 \%$ \\
\hline & Widowed & 4 & 11 & $7.4 \%$ \\
\hline \multirow{2}{*}{$\begin{array}{l}\text { Do you drink } \\
\text { alcohol }\end{array}$} & Yes & 11 & 15 & $12.7 \%$ \\
\hline & No & 57 & 121 & $87.3 \%$ \\
\hline \multirow{2}{*}{$\begin{array}{l}\text { Do you smoke } \\
\text { cigarettes }\end{array}$} & Yes & 1 & I & $1 \%$ \\
\hline & No & 67 & 135 & $99 \%$ \\
\hline
\end{tabular}

Abbreviations: ETB, Ethiopian birr, I USD=31.59 ETB; USD, United States dollar.

males (57.4\%): this shows a male gender bias in the prevalence of diabetic mellitus in this study. This is in line with a WHO report which shows a male gender bias in the prevalence of diabetic mellitus and it is in contradiction with a study conducted in Zimbabwe in 2011. ${ }^{10,15}$

In this study the median ages of cases and controls were $39.5(\mathrm{IQR}=28-50)$ and $389(\mathrm{IQR}=27.5-50)$, respectively. The results reveal that $29.4 \%$ of cases and $33.1 \%$ of 
Table 2 Disease, Treatment and Service Related Characteristics of Diabetic Follow-Up Patients at DMRH, North West Ethiopia, 2018

\begin{tabular}{|c|c|c|c|}
\hline \multirow[t]{2}{*}{ Variable } & \multirow[t]{2}{*}{ Category } & \multicolumn{2}{|c|}{ Frequencies } \\
\hline & & $\begin{array}{l}\text { Cases } \\
\mathrm{N}=68\end{array}$ & $\begin{array}{l}\text { Controls } \\
N=136\end{array}$ \\
\hline Duration after diagnosis & $\begin{array}{l}\leq 10 \text { years } \\
>10 \text { years }\end{array}$ & $\begin{array}{l}62(30.32 \%) \\
6(2.9 \%)\end{array}$ & $\begin{array}{l}129(63.23 \%) \\
7(3.4 \%)\end{array}$ \\
\hline Family history of DM & $\begin{array}{l}\text { Yes } \\
\text { No }\end{array}$ & $\begin{array}{l}14(6.8 \%) \\
54(26.47 \%)\end{array}$ & $\begin{array}{l}22(10.78 \%) \\
114(55.8 \%)\end{array}$ \\
\hline Type of treatment & $\begin{array}{l}\text { Insulin } \\
\text { OHA } \\
\text { Both }\end{array}$ & $\begin{array}{l}50(24.5 \%) \\
15(7.3 \%) \\
3(1.4 \%)\end{array}$ & $\begin{array}{l}76(37.25 \%) \\
50(24.5 \%) \\
10(4.9 \%)\end{array}$ \\
\hline $\begin{array}{l}\text { Distance from the health } \\
\text { institution }\end{array}$ & $\begin{array}{l}\leq 5 \mathrm{~km} \\
>5 \mathrm{~km}\end{array}$ & $\begin{array}{l}34(16.66 \%) \\
34(16.6 \%)\end{array}$ & $\begin{array}{l}80(39.21 \%) \\
56(27.45)\end{array}$ \\
\hline $\begin{array}{l}\text { Measure your blood } \\
\text { glucose at home }\end{array}$ & $\begin{array}{l}\text { Yes } \\
\text { No }\end{array}$ & $\begin{array}{l}8(3.9 \%) \\
60(29.41)\end{array}$ & $\begin{array}{l}19(9.3 \%) \\
117(57.3 \%)\end{array}$ \\
\hline BMI & $\begin{array}{l}\leq 18.5 \\
18.5 \_24.9 \\
25 \_29.9 \\
\geq 30\end{array}$ & $\begin{array}{l}7(3.4 \%) \\
41(20 \%) \\
19(9.3 \%) \\
1(0.4 \%)\end{array}$ & $\begin{array}{l}9(4.4 \%) \\
82(40.19 \%) \\
37(18.13 \%) \\
8(3.9 \%)\end{array}$ \\
\hline Systolic blood pressure & $\begin{array}{l}\leq 90 \mathrm{mmhg} \\
90 \_120 \mathrm{mmhg} \\
121 \_140 \mathrm{mmhg} \\
140 \_160 \mathrm{mmhg} \\
>160 \mathrm{mmhg}\end{array}$ & $\begin{array}{l}\text { I (0.4\%) } \\
46(22.5 \%) \\
9(4.4 \%) \\
10(4.9 \%) \\
2(0.9 \%)\end{array}$ & $\begin{array}{l}0 \\
88(43.13 \%) \\
23(11.27 \%) \\
23(11.27 \%) \\
2(0.9 \%)\end{array}$ \\
\hline Diastolic blood pressure & $\begin{array}{l}\leq 60 \mathrm{mmhg} \\
60 \_90 \mathrm{mmhg} \\
91 \_100 \mathrm{mmhg} \\
101 \_109 \mathrm{mmhg} \\
>110 \mathrm{mmhg}\end{array}$ & $\begin{array}{l}2(0.9 \%) \\
43(20.7 \%) \\
19(9.3 \%) \\
3(1.4 \%) \\
3(1.4 \%)\end{array}$ & $\begin{array}{l}\text { I }(0.4 \%) \\
69(38.2 \%) \\
51(25 \%) \\
12(5.8 \%) \\
3(1.4 \%)\end{array}$ \\
\hline $\begin{array}{l}\text { Self-reported drug } \\
\text { adherence }\end{array}$ & $\begin{array}{l}\text { Good } \\
\text { Poor }\end{array}$ & $\begin{array}{l}54(26.47 \%) \\
14(6.8 \%)\end{array}$ & $\begin{array}{l}124(60.7 \%) \\
\text { II (5.3\%) }\end{array}$ \\
\hline Glycemic control & $\begin{array}{l}<70 \mathrm{mg} / \mathrm{dL} \\
70-130 \mathrm{mg} / \mathrm{dL} \\
\geq 131 \mathrm{mg} / \mathrm{dL}\end{array}$ & $\begin{array}{l}16(7.8 \%) \\
27 \text { (13.23\%) } \\
25(12.25 \%)\end{array}$ & $\begin{array}{l}3(1.4 \%) \\
51(25 \%) \\
82(40.19 \%)\end{array}$ \\
\hline $\begin{array}{l}\text { Have ever received health } \\
\text { education }\end{array}$ & $\begin{array}{l}\text { Yes } \\
\text { No }\end{array}$ & $\begin{array}{l}63(30.88 \%) \\
5(2.4 \%)\end{array}$ & $\begin{array}{l}126(61.7 \%) \\
10(4.9 \%)\end{array}$ \\
\hline Type of diabetic mellitus & $\begin{array}{l}\text { Type } 1 \\
\text { Type } 2\end{array}$ & $\begin{array}{l}49(24.01 \%) \\
19(9.3 \%)\end{array}$ & $\begin{array}{l}69(33.8 \%) \\
67(32.8 \%)\end{array}$ \\
\hline
\end{tabular}

Abbreviations: OHA, oral hypoglycemic agents; $\mathrm{BMI}$, body mass index, normal BMI $18.5-24.5$

controls are found in the age group $>47$ years; this is the age group at which most cases and controls are found. This is similar to another study that showed a high frequency of diabetic complications was found in the older age group, and age increment was a significant factor for diabetic complications. ${ }^{9}$
Table 3 Knowledge and Attitude Status of Diabetic Follow-Up Patients at DMRH, North West Ethiopia, 2018

\begin{tabular}{|l|l|l|l|l|}
\hline Variable & Category & \multicolumn{2}{|l|}{ Frequencies } & \multirow{2}{*}{ Percentage } \\
\cline { 3 - 4 } & & $\begin{array}{l}\text { Cases } \\
(\mathbf{N}=68)\end{array}$ & $\begin{array}{l}\text { Controls } \\
(\mathbf{N}=136)\end{array}$ & \\
\hline Knowledge & Good knowledge & 58 & 113 & $83.2 \%$ \\
& Poor knowledge & 10 & 23 & $16.8 \%$ \\
\hline Attitude & Favorable attitude & 33 & 61 & $\begin{array}{l}46.1 \% \\
53.9 \%\end{array}$ \\
\hline
\end{tabular}

According to this study, $20.6 \%$ of cases responded as having poor drug adherence, but only $8.1 \%$ of controls have poor drug adherence, and this shows strict drug adherence could be crucial for a patient in preventing undesirable diabetic complication outcomes.

The study also shows that the majority of study subjects $(57.8 \%)$ are type 1 diabetic patients, $58.5 \%$ of cases and $41.5 \%$ of controls, respectively. When we assess the gender difference, out of the total males $60.7 \%$ and $54.0 \%$ out of the total females are type 1 diabetic, respectively. Regarding glycemic control, $62.5 \%$ of controls and $60.3 \%$ of cases have poor glycemic control.

In multiple logistic regression, the age groups of 38-47 years and $>47$ years, monthly income of 1000-1499, poor adherence, glycemic control, and type of diabetes are statically significant determinants of diabetic complications found in this study.

The odds of diabetic complication are 5.6 and 4.81 among the age groups $38-47$ and $>47$, respectively, as compared to the 18-27-year age group. This indicates that as age increases the probability of developing complications is higher. This could be due to altered glucose metabolism associated with aging due to the fact that aging results in relative insulin resistance and islet cell dysfunction, or it could be due to hormonal changes and decreased physical activity associated with aging that result in decreased insulin sensitivity. This result is similar to a study that was conducted at Ayder Referral Hospital, Bahirdar Referral Hospital, Dessie Referral Hospital, and India. But in a study which was conducted in Iran age was not a significant factor for diabetic complications; this difference could be due to sample size difference and matching of case and control on age and gender variables in the Iran study. ${ }^{12,16-18}$

Monthly income is another determinant variable for diabetic complications. The odds of developing diabetic 
Table 4 Determinants of Diabetic Complication Among Diabetic Follow-Up Patients at DMRH, North West Ethiopia, 2018

\begin{tabular}{|c|c|c|c|c|c|c|}
\hline Variable & Category & Cases $(\mathrm{N}=68)$ & Controls $(N=136)$ & COR(95\% Cl) & AOR(95\% Cl) & $P$-value \\
\hline Age & $18-27$ & 15 & 34 & 1.00 & 1.00 & \\
\hline Monthly income in ETB & $\begin{array}{l}28-37 \\
38-47 \\
>47 \\
<500 \\
500-999 \\
1000-1499 \\
1500-1999 \\
\geq 2000\end{array}$ & $\begin{array}{l}15 \\
18 \\
20 \\
9 \\
10 \\
11 \\
6 \\
32\end{array}$ & $\begin{array}{l}32 \\
25 \\
45 \\
22 \\
15 \\
12 \\
10 \\
77\end{array}$ & $\begin{array}{l}1.06(0.44-2.51) \\
1.63(0.69-3.84) \\
1.01(0.45-2.25) \\
0.97(0.26-1.97) \\
1.61(0.61-5.18) \\
2.20(0.83-2.53) \\
1.45(0.60-6.28) \\
1.00\end{array}$ & $\begin{array}{l}1.02 *(0.33-3.15) \\
5.60 *(1.62-19.38) \\
4.81(1.32-17.5) \\
0.51(0.15-1.69) \\
1.73(0.46-6.54) \\
3.10 *(1.05-9.08) \\
3.27(0.82-13.07) \\
1.00\end{array}$ & $\begin{array}{l}0.963 \\
0.007^{*} \\
0.017^{*} \\
0.269 \\
0.413 \\
0.040^{*} \\
0.09\end{array}$ \\
\hline Marital status & $\begin{array}{l}\text { Single } \\
\text { Married } \\
\text { Divorced } \\
\text { Widowed }\end{array}$ & $\begin{array}{l}17 \\
41 \\
6 \\
4\end{array}$ & $\begin{array}{l}37 \\
85 \\
3 \\
11\end{array}$ & $\begin{array}{l}1.00 \\
1.05(0.52-2.08) \\
4.35(0.97-19.5) \\
0.79(0.22-2.84)\end{array}$ & $\begin{array}{l}1.00 \\
0.79(0.25-2.5) \\
4.03(0.49-32.77) \\
0.34(0.04-3.6)\end{array}$ & $\begin{array}{l}0.69 \\
0.19 \\
0.34\end{array}$ \\
\hline Residence & $\begin{array}{l}\text { Urban } \\
\text { Rural }\end{array}$ & $\begin{array}{l}39 \\
29\end{array}$ & $\begin{array}{l}99 \\
37\end{array}$ & $\begin{array}{l}1.00 \\
1.99(1.08-3.66)\end{array}$ & $\begin{array}{l}1.00 \\
0.8 I(0.28-2.4 I)\end{array}$ & 0.71 \\
\hline Types of drug & $\begin{array}{l}\text { Insulin only } \\
\text { OHA } \\
\text { Both }\end{array}$ & $\begin{array}{l}50 \\
15 \\
3\end{array}$ & $\begin{array}{l}76 \\
50 \\
10\end{array}$ & $\begin{array}{l}2.19(0.58-8.36) \\
1.00(0.24-4.1) \\
1.00\end{array}$ & $\begin{array}{l}1.53(0.06-35.63) \\
3.12(0.45-21.36) \\
1.00\end{array}$ & $\begin{array}{l}0.79 \\
0.246\end{array}$ \\
\hline $\begin{array}{l}\text { Distance from } \\
\text { hospital }\end{array}$ & $\begin{array}{l}<5 \mathrm{~km} \\
\geq 5 \mathrm{~km}\end{array}$ & $\begin{array}{l}34 \\
34\end{array}$ & $\begin{array}{l}80 \\
56\end{array}$ & $\begin{array}{l}1.00 \\
1.43(0.79-1.26)\end{array}$ & $\begin{array}{l}1.00 \\
0.7 I(0.28-2.57)\end{array}$ & 0.46 \\
\hline Adherence to treatment & $\begin{array}{l}\text { Good } \\
\text { Poor }\end{array}$ & $\begin{array}{l}54 \\
14\end{array}$ & $\begin{array}{l}124 \\
11\end{array}$ & $\begin{array}{l}1.00 \\
2.92(1.24-6.85)\end{array}$ & $\begin{array}{l}1.00 \\
5.15 *(1.65-16.04)\end{array}$ & $0.05^{*}$ \\
\hline BMI & $\begin{array}{l}<18.5 \mathrm{k} . \mathrm{g} / \mathrm{m}^{2} \\
18.5-24.9 \mathrm{k} . \mathrm{g} / \mathrm{m}^{2} \\
25-29.9 \mathrm{k} . \mathrm{g} / \mathrm{m}^{2} \\
\geq 30 \mathrm{k} . \mathrm{g} / \mathrm{m}^{2}\end{array}$ & $\begin{array}{l}7 \\
41 \\
19 \\
1\end{array}$ & $\begin{array}{l}9 \\
82 \\
37 \\
8\end{array}$ & $\begin{array}{l}1.00 \\
6.2(0.62-62.15) \\
4.00(0.49-33.07) \\
4.1(0.47-35.31)\end{array}$ & $\begin{array}{l}1.00 \\
0.38(0.06-2.36) \\
0.8(0.10-6.19) \\
0.18(0.01-3.63)\end{array}$ & $\begin{array}{l}0.296 \\
0.83 \\
0.26\end{array}$ \\
\hline Glycemic control & $\begin{array}{l}<70 \mathrm{mg} / \mathrm{dL} \\
70-130 \mathrm{mg} / \mathrm{dL} \\
\geq 131 \mathrm{mg} / \mathrm{dL}\end{array}$ & $\begin{array}{l}16 \\
27 \\
25\end{array}$ & $\begin{array}{l}3 \\
51 \\
82\end{array}$ & $\begin{array}{l}1.00 \\
0.09(0.03-0.37) \\
0.06(0.02-0.22)\end{array}$ & $\begin{array}{l}I .00 \\
0.09 *(0.02-0.4 I) \\
0.05 *(0.0 I-0.22)\end{array}$ & $\begin{array}{l}0.02 * \\
<0.00 I^{*}\end{array}$ \\
\hline Types of diabetes & $\begin{array}{l}\text { Type } 1 \\
\text { Type } 2\end{array}$ & $\begin{array}{l}49 \\
19\end{array}$ & $\begin{array}{l}69 \\
67\end{array}$ & $\begin{array}{l}2.50(1.34-4.69) \\
1.00\end{array}$ & $\begin{array}{l}4.73 *(1.76-12.72) \\
1.00\end{array}$ & $0.02 *$ \\
\hline
\end{tabular}

Notes: *Statistically significant; the odds ratio for each variable or factors was adjusted for determinant factors like age, monthly income, adherence, and type of diabetes mellitus. Abbreviations: OHA, oral hypoglycemic agents; KM, kilometer; ETB, Ethiopian birr, IUSD= 3I.59 ETB; USD, United States dollar.

complications among groups who earned 1000-1499 monthly income is 3.1 as compared to those who earned $>2000$ monthly income. The result shows us that low income was another contributing factor for diabetic complications. This might be due to the fact that those who had lower income would wait longer times in accessing health services. This might contribute to worse complications, such as acute diabetic complications. It could be also due to psychological distress accompanied by the poor economic status that could result in poor glycemic control. The finding is similar to the study conducted in Ayder hospital, but it was different from the study conducted in India and Dessie Referral Hospital. The difference could be due to a cross-sectional study design used by two of the areas. $^{9,11,16}$

Adherence is another determinant variable of this study, as the result shows the odds of diabetic complication is 5.14 in poorly adhered diabetic patients as compared to those who strictly adhered to treatment drugs. The significant association of adherence and diabetic complication implies that aggressive treatment adherence will keep blood glucose as close as normal and optimum glycemic 
Table 5 Frequency Distribution of Diabetic Patients Knowledge Score Of Diabetes Mellitus, Management, and Complication in Debre Markos Referral Hospital, North West Ethiopia, 2018 ( $\mathrm{N}=204)$

\begin{tabular}{|c|c|c|c|c|}
\hline \multirow[t]{2}{*}{ Variable } & \multicolumn{2}{|l|}{ Yes } & \multicolumn{2}{|c|}{ No } \\
\hline & $\mathbf{N}$ & $\%$ & $\mathbf{N}$ & $\%$ \\
\hline Diabetic mellitus is a condition of incomplete insulin production & 105 & 51.5 & 99 & 48.5 \\
\hline DM is a condition of high level of sugar in blood & 156 & 76.5 & 48 & 23.5 \\
\hline DM is not curable & 157 & 77 & 47 & 23 \\
\hline DM is a condition of body which is not responding to insulin & 106 & 52 & 98 & 48 \\
\hline Insulin is important for management of DM & 126 & 61.8 & 78 & 38.2 \\
\hline Tablets are important for control of management of DM & 134 & 65.7 & 70 & 64.3 \\
\hline Regular exercise is important for control of DM & 148 & 72.5 & 56 & 27.5 \\
\hline Healthy diet practice is important for controlling DM & 158 & 77.5 & 46 & 22.5 \\
\hline Medical eye check-up should be taken for DM & 169 & 82.8 & 35 & 17.2 \\
\hline Medical feet and toe check-up should be taken & 171 & 83.8 & 33 & 16.2 \\
\hline Weight reduction is good for controlling DM & 174 & 85.3 & 30 & 14.7 \\
\hline If DM is poorly managed it can lead to severe hyperglycemia & 178 & 87.3 & 26 & 12.7 \\
\hline If DM is poorly managed it can lead to hypoglycemia & 184 & 90.2 & 20 & 9.8 \\
\hline If DM is poorly managed it can lead to feet amputation & 178 & 87.3 & 26 & 12.7 \\
\hline If DM is poorly managed it can lead to kidney problem & 173 & 84.8 & 31 & 15.2 \\
\hline
\end{tabular}

Table 6 Frequency Distribution of Diabetic Patients Attitude Score by Likert Scales Regarding Diabetic Mellitus in Debre Markos Referral Hospital, North West Ethiopia, $2018(\mathrm{~N}=204)$

\begin{tabular}{|l|l|l|l|l|l|}
\hline Variable & \multicolumn{2}{l|}{ Attitude Rate } \\
\cline { 2 - 7 } & $\begin{array}{l}\text { Strongly Agree } \\
\text { N (\%) }\end{array}$ & $\begin{array}{l}\text { Agree } \\
\text { N (\%) }\end{array}$ & $\begin{array}{l}\text { Neutral } \\
\text { N (\%) }\end{array}$ & $\begin{array}{l}\text { Disagree } \\
\text { N (\%) }\end{array}$ & $\begin{array}{l}\text { Strongly Disagree } \\
\text { N (\%) }\end{array}$ \\
\hline I do not mind if others know that I am with diabetes & $18(3.9)$ & $14(6.9)$ & $3(1.5)$ & $96(47.1)$ & $83(40.7)$ \\
I think that family members should screened for diabetes & $4(2)$ & $9(4.4)$ & $3(1.5)$ & $80(39.2)$ & $108(52.9)$ \\
I think support from family is important in dealing with DM & $3(1.5)$ & $28(13.7)$ & $9(4.4)$ & $80(39.2)$ & $84(41.2)$ \\
I think diabetes mellitus seriously affects daily activities & $7(3.4)$ & $45(22.1)$ & $6(2.9)$ & $81(39.7)$ & $65(31.9)$ \\
I think diabetes mellitus complication affects marital relationship & $9(4.4)$ & $4 I(20.1)$ & $12(5.9)$ & $75(36.8)$ & $67(932.8)$ \\
I think poor drug adherence will lead me to poor glycemic control & $7(3.4)$ & $31(15.2)$ & $8(3.9)$ & $77(37.7)$ & $81(39.7)$ \\
If glucose is well monitored complication is unlikely & $5(2.5)$ & $22(10.8)$ & $9(4.40)$ & $81(39.7)$ & $87(42.6)$ \\
I am diabetic does not mean I had complication & $7(3.4)$ & $16(7.80)$ & $10(4.9)$ & $81(39.7)$ & $90(44.1)$ \\
\hline
\end{tabular}

control will be achieved to prevent undesirable complications. This is in contradiction to the study from Dessie Referral Hospital that self-reported drug adherence was not associated with diabetic complications; this difference could be because of the study design and sample size difference. But a study conducted in Zimbabwe had a similar finding. ${ }^{10,11}$

This study showed that glycemic control is also another significantly associated determinant variable. The odds of diabetic complication is 0.095 among patients who had good glycemic control as compared to those who had mean FBS below $70 \mathrm{mg} / \mathrm{dL}$. This finding means those who had good glycemic control had $90.5 \%$ less risk of developing diabetic complications. On the other hand, those who had mean fasting blood glucose $\geq 131 \mathrm{mg} / \mathrm{dL}$ had $95 \%$ less risk of developing diabetic complications as compared to their counterparts. This finding is also supported by the study from Ayder Referral Hospital but it is different from other literature; such as the study in Zimbabwe. The difference could be because of the difference in source population characteristics and sample size difference. ${ }^{9,10}$

Type 1 diabetic patients were found to be significantly associated with diabetic complications; the probability of developing diabetic complications is 4.73 times higher among type 1 diabetic patients as compared to type 2 patients; this finding is similar to a report of the American diabetic association standard of medical treatment 2013. According to the report, type 1 diabetic patients are highly 
at risk of developing diabetic complications unless strict adherence is maintained. Because patients with type 1 diabetic mellitus have absolute insulin deficiency, even missing treatment on one occasionwill result in hyperglycemia and other hyperglycemia-related complications. ${ }^{19,20}$

\section{Limitation of the Study}

The biased nature of the study design is one of the possible limitations of this study because cases can recall the events better than controls in the area of interest. Matching has a potential benefit in preventing confounding so this study could have limitation on addressing it. A lack of availability of the $\mathrm{HgAlc}$ test result to estimate glycemic control level of study subjects was another limitation of the study.

\section{Conclusion and Recommendation Conclusion}

The study tried to identify some important parameters that are possible determinants of diabetic complications. According to the findings, income, glycemic control, and adherence were found to be modifiable determinants of diabetic complications; whereas age and type of diabetic mellitus are non-modifiable determinates of diabetic complications.

\section{Recommendation}

The investigator recommends all stakeholders to use their maximum effort in preventing the occurrence of undesirable diabetic complication outcomes by identifying clinically important parameters and prioritizing them for immediate intervention. Patients should shoulder much of the responsibility in preventing the complications because diabetic mellitus, similar to other chronic diseases, needs self-care capability to attain a maximum best outcome.

Health workers in health institutions should identify patients' self-care demands and address patient needs by using a compressive care plan that includes a patientcentered approach to attain good glycemic control and improve treatment adherence. As this research finally shows, most of the determinants will not be determinants once again if the patient's potential for preventing diabetic complications is maximized. Successful diabetes care requires a systematic approach to support patients' behavior change efforts, so clinicians and health-care teams should take responsibility and make efforts to change patient behavior. Health-care providers also need to be responsible for undertaking the regular evaluation of barriers to treatment outcomes, if patients are not meeting the desired level of outcome. The Ministry of Health, as a government organization, should also design clear and feasible diabetic complication prevention policies and strategies. The government should design health policies that moderate economic imbalances among different populations.

Finally, we recommend that other investigators conduct a matched case control study with a large sample size to control potential confounders and bring more reliable determinants of diabetic complications.

\section{Abbreviations}

AACE, American Association of Clinical Endocrinologists; BMI, body mass index; DM, diabetes mellitus; DKA, diabetic ketoacidosis; DMRH, Debre Markos Referral Hospital; ESRD, end-stage renal disease; FBG, fasting blood glucose; HgbAlc, glaciated hemoglobin; HHNS, hyperglycemic hyperosmolar non-ketosis coma; HTN, hypertension; IDDM, insulin-dependent diabetes mellitus; IDF; international diabetic federation; Mosm/L, milliosmolality per liter; NIDDM, non-insulin dependent diabetic mellitus; NKF, national kidney foundation; OHA, oral hypoglycemic agents; OPD, outpatient department; RBS, random blood glucose test; SPSS, statical product and service solution; T2DM, type 2 diabetic mellitus; USD, United States dollar; WHO, World Health Organization.

\section{Ethical Approval and Consent to Participate}

All participants provided written informed consent, and the study was conducted in accordance with the Declaration of Helsinki. The ethical letter was obtained from Debre Markos University, Health Science College of Ethical review committee. For data quality assurance two days of training were given for data collectors and supervisors prior to data collection. The supervisors monitored the data collection process during the data collection period by checking the completeness of the data and taking the correction on the site of data collection when any problems happened. The principal investigator checked data for its completeness during data entry and the cleaning process.

\section{Data Sharing Statement}

The dataset will not be shared in order to protect the participants' identities.

\section{Acknowledgment}

We would like to thank data collectors and supervisors for their great contribution and timely submission of filled questionaires. Our sincere thanks also go to Debre Markos 
Referral Hospital administrative staff for their permission to participate in this thesis work. We want to extend our heartfelt gratitude to Debre Markos University for giving us all the necessary and available services to conduct this study.

\section{Author Contributions}

All authors made substantial contributions to conception and design, acquisition of data, or analysis, and interpretation of data; took part in drafting the article or revising it critically for important intellectual content; gave final approval of the version to be published; and agree to be accountable for all aspects of the work. BB conceived and designed the study, performed analysis and interpretation of data. GA and HZ advised and supervised the design conception, analysis, interpretation of data and made critical comments at each step of research. $\mathrm{MG}, \mathrm{AE}$, and AA drafted the manuscript. All authors read and approved the final manuscript.

\section{Disclosure}

The authors declared no conflict of interest.

\section{References}

1. IDF. Global guideline for managing older people with type 2 diabetes. Brussels Belgium. 2013;13:16-22.

2. Tripathi BK, Srivastava AK. Diabetes mellitus: complications and therapeutics. Med Sci Monit. 2006;12(7):RA130-RA47.

3. Deshpande AD, Harris-Hayes M, Schootman M. Epidemiology of diabetes and diabetes-related complications. Phys Ther. 2008;88 (11):1254-1264. doi:10.2522/ptj.20080020

4. Zhang P, Zhang X, Brown J, et al. Global health expenditure on diabetic mellitus. Diabetes Res Clin Pract. 2010;87:293-301. doi:10.1016/j.diabres.2010.01.026

5. El-Sadig FA, El-Sadig M. Prevalence of risk factors for diabetic foot complications. BMC Fam Pract. 2007;8:59. doi:10.1186/1471-2296$8-59$

6. IDF. Diabetes Atlas Eighth Edition; 2017.
7. International Diabetes Federation. Diabetes Atlas. 7th. IDF; 2015.

8. Abebe N, Kebede T, Kebede D. Addise diabetes in Ethiopia 2000-2016 prevalence and related factors a systematic review. Afr $J$ Diabetes. 2017;25(2):7-12.

9. Daniel N, Iika A, Debora A. Complication and the time of diagnosis of diabetes mellitus in primary care. Acta Paul Enferm. 2015;28 (3):250-255.

10. Bommer C, Sagalova V, Hessemann E, Manne-Goehler J, Atun R. Global economic burden of diabetes in adults; projections from 2015-2030. Diabetes Care. 2018;41:963-970. doi:10.2337/dc17-1962

11. Hintsa S, Dube L, Mebrahtu Abay TA, Workicho A. Determinants of diabetic nephropathy in Ayder Referral Hospital, Northern Ethiopia: a case-control study. PloS one. 2015;12(4).

12. Ponesai N, Anderson C, Mufuta T, Gombe N, Lucia T, Donewell B. Risk factors for diabetic complications among diabetic patients, Chirumanzu district, Zimbabwe, 2011. Austin J Public Health Epidemiol. 2015;2.

13. Abejew AA, Belay AZ, Kerie MW. Diabetic Complications Among Adult Diabetic Patients of a Tertiary Hospital in Northeast Ethiopia. Hindawi. 2015.

14. Mariam TG, Alemayehu A, Tesfaye E, et al. Prevalence of diabetic foot ulcer and associated factors among adult diabetic patients at the University of Gondar Referral Hospital. Hindawi J Diabetes Res. 2016;2017:8

15. Kassahun CW, Mekonen AG. Knowledge, attitude, practices and their associated factors towards diabetes mellitus among non-diabetes community members of Bale Zone administrative towns, South East Ethiopia. A cross- sectional study. PLoS One. 2017;12. doi:10.1371/journal.pone. 0170040

16. WHO. Definition and Diagnosis of Diabetes Mellitus and Intermediate Hyperglycemia, Internet; 2006.

17. Bansal D, Gudala K, Esam HP, Nayakallu R, Vyamusani RV, Bhansali A. Microvascular complications and their associated risk factors in newly diagnosed type 2 diabetes mellitus patients. Hindawi Int J Chron Dis. 2014;2014.

18. Lebeta R, Argaw Z, Walle B. Prevalence of diabetic complications and its associated factors among diabetes mellitus patients attending diabetes mellitus clinics; institution based cross sectional study. Am $J$ Health Res. 2017;5(2):38-43. doi:10.11648/j.ajhr.20170502.13

19. Kogani M, Mansournia MA, Doosti-Irani A, Holakouie-Naieni K. Risk factors for amputation in patients with diabetic foot ulcer in southwest iran: a matched case-control study. Epidemiol Health. 2015;37:e2015044. doi:10.4178/epih/e2015044

20. American diabetic association. Standards of medical care in diabetes. J Diabetes Care. 2013;36:s11-s66. doi:10.2337/dc13-S011

Diabetes, Metabolic Syndrome and Obesity: Targets and Therapy

Dovepress

\section{Publish your work in this journal}

Diabetes, Metabolic Syndrome and Obesity: Targets and Therapy is an international, peer-reviewed open-access journal committed to the rapid publication of the latest laboratory and clinical findings in the fields of diabetes, metabolic syndrome and obesity research. Original research, review, case reports, hypothesis formation, expert opinion and commentaries are all considered for publication. The manuscript management system is completely online and includes a very quick and fair peer-review system, which is all easy to use. Visit http://www.dovepress.com/testimonials.php to read real quotes from published authors. 